\title{
The Concept of God in Beowulf and The Book of Dede Korkut
}

\author{
Hülya Taflı \\ Erciyes University
}

Epic is an extended narrative poem, grand in scope, exalted in style, and heroic in theme, often giving expression to the ideals of a nation or race (Legouis: 1943: 22). Although the locations and the eras of the epics differ, the similarities of conditions bring them into existence. In this article Beowulf, the English epic, and The Book of Dede Korkut, the Turkish epic, are going to be compared in order to depict the similarities and the differences of the concept of God in different locations and eras.

The geographical location of Beowulf is in the northwest of England and The Book of Dede Korkut is is in the north of Anatolia. Orchard states that the geographical location of Beowulf is around the Baltic Sea and the North Sea where the Swedes, Jutes, Geats, Danes, Angles, Heathobards and Frisians lived (2003: xiii). When these tribes are compared chronologically, it can be seen that the Angles were highly influenced by the Danes, Geats, and other Germanic and Scandinavian tribes. Cherniss asserts that these tribes may be considered to be the ancestors of the English; the scops may have travelled among the tribes of Germania and the documents of the travels highlight the ancestors of the English (1972: 14). On the other hand the geographical location of The Book of Dede Korkut is around the Caspian Sea and the Black Sea, in what is today Asia. The Huns, once members of the ancient Göktürk Empire, moved westward to settle along the banks of the Syr 
Darya, then westward to the shores of the Caspian Sea, south to Transoxiana and northward to the steppes beyond the Aral Sea (Elibeyzade 1988: 1).

It is generally accepted that The Book of Dede Korkut was put down into writing in the ninth century (Ergin 1989: 56) and Beowulf was put down into writing some time between the middle of the seventh and the end of the tenth century of the first millenium, in Anglo-Saxon or Old English (Heaney 2002: xxiii). Although they were put down into writing two centuries apart, there are certain characteristics common to these two epics. It may be asserted that both epics have common characteristics though composed at different times and in different places. As stated by Binyazar each epic posesses the characteristics of the heroic and folk epic tradition: history and imagination, mythology and folklore are intermingled in them (1996: 78), but Çobanoğlu suggests that these epics cannot be thought of as historical documents, which show verisimilitude (2003: 20). Structurally, Beowulf consists of three tales and the deeds of a single hero, whereas The Book of Dede Korkut consists of twelve tales, a prologue and the deeds of the wise man 'Dede Korkut'" . They also differ in form; Beowulf was put down into writing in verse, but The Book of Dede Korkut was put down into writing in alternating verse and prose.

The traces of deities and the concept of God are observed in both Beowulf and The Book of Dede Korkut. Beowulf was composed some time between the middle of the seventh and the end of the tenth century of the first millenium (Heaney 2002: xxiii). The Book of Dede Korkut was composed some time between the fifth and the seventh century of the first millenium (Nebiyev 2000: 66). The societies depicted in Beowulf were pagans and this pagan belief came from the Druids and the Germanic tribes (North 1997: 185). Similar to this, the societies depicted in The Book of Dede Korkut were the oğuz people who were considered to

\footnotetext{
' In The Book of Dede Korkut, Dede Korkut is sometimes observed as Korkut Ata.
} 
be the believers of the Sky-God belief and shamanism. These epics were being sung and put down into writing, and during this process the societies were being converted to monotheistic religions, that is, Christianity and Islam respectively.

The concept of paganism is implicitly embodied in Beowulf. As stated by Bjork, the Danes are said to have engaged in the actual worship of heathen gods, for which the Christian poet of Beowulf condemns them, though realizing with some sympathy that they cannot help their ignorance (1997: 178). Though the Danes were pagans, there is not any kind of actual pagan worship; no pagan gods are ever referred to, and there is no explicit mention of their being pagans. Cherniss points out that in Beowulf there are several clues in which are the remnants of the Germanic pagan tradition (1972: 26). Most of the Scandinavian myths refer to the deities of nature and their deeds. Othin was called "Allfather"; he was not only the actual father of many of the gods and created the first man and woman, but he was also foremost of the gods. Snorri states that:

Othin is the highest and oldest of the gods. He rules all things and, no matter how mighty the other gods may be, they all serve him as children do their father. He lives forever and ever, and rules over the whole of his kingdom and governs all things great and small. He created heaven and earth and sky and all that is in them. (Crossley-Holland 1980: xxv)

Thor, son of Othin and Earth, was second in the pantheon and he represents order, when his father stands for violence and war. The most important of the fertility gods was Freyr, god of Plenty; he decides when the sun shall shine or the rain come down, and along with that the fruitfullness of the earth, and he is the god to invoke for peace and plenty. Frigg is Othin's wife but no information is given about her in the Scandinavian myths. Similar to Crossley-Holland's comments, Chadwick suggests that the gods are grouped together in an organized community: 
Othin is considered to be the head, Frigg is considered to be Othin's wife and Thor and many of the other gods are considered to be the other members of the Scandinavian community (Chadwick 1912: 394).

It may be possible that the poet of Beowulf depicts the religious beliefs of his characters especially by choosing Germanic and Scandinavian heroes and rituals as his subject matters. Many of the scholars hold the point of view that the poet of Beowulf might have been a pious Christian priest, and that he might implicitly have imposed the doctrines of Christianity onto the pagan poem (Orchard 2003: 99; Cherniss 1972: 9; Clark 1990: 37). It is also interesting that there is no specific source of the poet or the poets of Beowulf either; hence the identity of the composer or the composers of the English epic is still under debate. As stated by Clark, the Anglo-Saxons themselves began to accept Christianity only from the late six century on, and throughout this period paganism was a constant threat against which preachers railed, and Christian kings and their retinues struggled (1990: 33). When the Beowulf poet sets out to show how admirable and at the same time how examplary his non-Christian ancestors could be, he had to be very careful not to appear to be encouraging a return to the dark ways of Germanic and Scandinavian heathendom. The poet celebrates the nobility of Beowulf and the religious beliefs, which any Anglo-Saxon would have known to be Germanic and Scandinavian paganism. The poet speaks of the true God and of the Devil, and he alludes specifically to biblical events such as the Flood, the Last Judgement, and Cain's slaying of Abel. These biblical narratives explicitly alluded to in Beowulf are connected to Grendel, and the passages referring to Cain places Grendel directly in the race of the first murderer in the Old Testament.

As Godden also points out, Grendel is introduced with a reference to the Old Testament legend which describes the origin of the monsters, so his end is 
announced by an allusion to the biblical myth of their destruction (?: 216). In the poem, the thoughts of the characters and their language are circumscribed by the pagan world in which they live, and at times their speeches seem to have a Christian resonance. North draws attention to the fact that the audience is expected to understand the two different cultures which inevitably give dignity to the old heroes as viewed by Christian eyes, but which betray no Christian revelation in heathen minds (1997: 185). The poet of Beowulf is a Christian and like him most of the Teutonic peoples are considered to have accepted Christianity. Similar to the views of North, Chadwick asserts that

The facts which are known with regard to the conversion are that it almost invariably began in the king's court; that violent opposition was offered only in kingless communities, as among the Old-Saxons, or in defiance of the king's authority, as in Norway; that after the conversion the gods (in general) disappear at once and for good; that magical practices and the belief in spirits and even in certain female agricultural deities lasted among the country people for many centuries. (1912: 414)

If the reflection of paganism in Beowulf is examined closely, it will be seen that it can be classified in three groups according to how it has been employed in the poem. The first type can be defined as the literal use of paganism. It refers to the actual practice and beliefs of pre-Christian Germanic peoples. These practices and beliefs are considered to be the rituals of polytheistic societies, and ship burial might be given as an example for the literal display of paganism. The societies depicted in Beowulf are pre-Christian, and the epic embodies the literal descriptions of pagan religious rituals as illustrated in the lines below where the burial of the lord according to pagan rituals is described:

They shouldered him out of the sea's flood, The chief they revered who had long ruled them. 
A ring-whorled prow rode in the harbour, Ice-clad, outbound, a craft for a prince.

They stretched their beloved lord in his boat, Laid out by the mast, amidships, The great ring giver. Far fetched treasures Were piled upon him, and precious gear. I never heard before of a ship so well furbished With battle-tackle, bladed weapons And coats of mail

No man can tell, No wise man in hall or weathered veteran Knows for certain who salvaged that load $(30-52)^{2}$

Christian authorities condemned the pagan funeral rites of this kind, and the ship burial of a Christian ritual was observed. The ship of Shield is not buried in a mound, which is considered to be a Christian ritual, but pushed out to the sea. Shield, who establishes the Danish royal family, dies and is pushed out the sea according to a Christian ritual. Similar to this, Beowulf is the predecessor of the royal Geat family, and Beowulf's funeral is another example of the direct literal depiction of pagan beliefs (3134-82).

The second method of depicting paganism in Beowulf can be defined as vestigial paganism, which refers to the traces of fossil paganism such as the use of the description of pagan dresses, armours, amulets, helmets and swords. Archeologists have focused on materials such as the helmets with boar images that people used in their day-to-day lives (Barrett 1990: 121). These helmets with boar images were found at Sutton Hoo, Suffolk, that date from the seventh century (Bruce-Mitford 1968: 1965-67). Similarly, the warriors in Beowulf wear helmets with images of boars on them:

So they went on their way. The ship rode the water, Broad-beamed, bound by its hawser

And anchored fast. Boar-shapes flashed

\footnotetext{
${ }^{2}$ In this study Seamus Heaney's Beowulf (Norton\&Company, New York 2003) translation into modern English has been used and further quotations are from this translation.
} 
Above their cheek-guards, the brightly forged Work of goldsmith, watching over

Those stern-faced men (300-306)

The boar was an animal sacred to the Germanic God Freyr, and its image was regarded as powerful protection (Bjork 1997: 179).

Owen and Crocker state that the boar as a symbol seems to have had a much longer existence and a wider currency than the boar helmet: Tacitus mentions the wearing of boar masks, probably in crop fertility ceremonies of the god Freyr which was well known in the North (2000: 117). Another example of vestigial paganism is the concept of fate. The concept is personified and is referred to as a god or goddess of Fate (Klaeber 1950: xliv). Hill points out that a man can change his fate or God can change the man's fate, and this metaphorical point of view may also be used literally:

My household guard are on the wane,

Fate sweeps them away

Into Grendel's clutches- but God can easily

Halt these raids and horrowing attacks (473-77)

Often for undaunted courage,

Fate spares the man it has not already marked (573-74)

In these lines Grendel's attacks on Heorot are given, and fate is considered to be a god-like creature. Beowulf is going to kill Grendel and his mother comes to take revenge. After Grendel's mother comes, her revenge seems to be inevitable, her arrival is clearly anticipated by the poet, but the sequence of actions, including the accidents of her foray and the defense of the hall, is a surprise. Fate is revealed in the event, a mystery not in fact fully realized until the event comes to a close. Even Beowulf's fight with the dragon in the last episode of the epic, despite forebothings and his spiritual restlessness, is an entry into the unknown. Beowulf does not know how many times the dragon will attack, nor does he know whether or not Wiglaf will 
come to his assistance, and he does not know how the dragon will be dispatched. It is fate who decides about all these things:

He was sad at heart unsettled yet ready, Sensing his death. His fate hovered near, unknowable but certain It would soon claim his coffered soul Part life from limb (2421-27)

The third method of depicting paganism in Beowulf lies in the realm of ethics and morality. As Irving points out, the fundamental ethical code of Beowulf is to some extent secular (1997: 180). It is the warrior code of aristocracy, celebrating bravery, loyalty and generosity, with the hero finding his immortality in the long lasting fame of great exploits carried out in this world. Irving also draws attention to the fact that in Scandinavian mythology and in Beowulf a similar code is sanctioned (1997: 180) The god Othin (Woden) rewards his warriors with a place in Valhalla, and this ritual may be observed in Beowulf because the hero is mourned and also immortalized by his people. The traces of paganism can be observed in Beowulf, but the poet condemns Hrothgar and the Danes for idol worship; he is consistent and careful in depicting the good pre-Christian heroic figures in the poem as monotheistic "Noachites". As defined by Hill, the religion of Beowulf, Hrothgar and the good Germanic heroes in the poem may be defined as "Noachitism", that is, as gentiles who share the religious heritage and knowlegde of Noah and his sons without having access to the revealed knowledge of God which was granted to Abraham, Isaac, and Jacob, a tradition culminated by the revelation of the Law to Moses and continued by the tradition of the prophecy in Israel (2003: 203). Hrothgar, the king of the Danes, is an examplary character displaying nobility, bravery, loyalty and generosity in terms of ethical paganism, but he worships the deities and is denounced by the poet: 
Sometimes at pagan shrines they vowed

Offering to idols, swore oaths

That the killer of souls might come to their aid

And save the people. That was their way, Their heathenish hope; deep in their hearts

They remembered hell. The Almighty Judge

Of good deeds and bad, the Lord God, Head of the Heavens and High King of the World,

Was unknown to them. Oh, cursed is he

Who in time of trouble has to thrust his soul

In the fire's embrace, forfeiting help;

He has nowhere to turn (175-86)

The English epic has both pagan and Christian elements, and Thorkelin believes that the poem has been composed by a Danish poet and then imported to England and slightly Christianized, possibly by King Alfred (www.nationmaster.com/encyclopedia/Thorkelin). If the similarities of Beowulf and its previous literary periods are studied in detail, it is possible to point out that the pre-Christian poet of this English pagan epic speaks of the poem as being based on 'The Myth of Beowa', the divine hero who overcame the sea-giant Grendel (Bjork 1997: 181). Beowa is identified with the old God Beowa who is the god of early pagan German epics. In this respect it may be stated that Beowulf embodies pagan motifs and after conversion to Christianity, pagan materials with Christian colouring are stressed in the epic (Bazelmans 1999: 72). Similarly, Klaeber acknowledges that the poem abounds in supernatural elements of pre-Christian associations, but asserts that nevertheless the general impression is decidedly Christian. Klaeber further argues that the general tone and the ethical viewpoint are predominantly Christian and that the main story has been thoroughly imbued with the spirit of Christianity (1912: 169-199). The predominant early view of the poem saw it as an essentially pagan poem, drawn from pre-Christian materials which once existed without Christian sentiments and allusions. Cherniss asserted that the Christian elements are of the most elementary nature and are mere colouring added by a 
pious interpolator (1972: 126). Blackburn (1897: 1-21) and Munro Chadwick (1912: 47-56) also argued for this interpolation theory. Although Christianity had been introduced into Roman Britain around the year $200 \mathrm{AD}$, and had persisted in parts of the island through the period of heathen Saxon invasion and settlement, it was not until 597, when Pope Gregory the Great sent his monk Augustine to reconvert Britain to the Roman doctrine, that Orthodox Latin Christianity began to gain ascendany there (Cherniss 1972: 10). In this respect it may be pointed out that Beowulf both preserves the virtues of polytheism and Chrsitianity.

The three methods of reflecting paganism depict that the concept of God are embodied in the Germanic heroic tradition that may shed light into the interaction of Germanic paganism and Christianity in Beowulf. As Cherniss states most of the stories such as The Thedrik Saga, Volsunga Saga, Nibelungenlied and Edda were lost in the period of the Germanic migrations, but they reappeared in the twelfth century and Beowulf contains the fragments of these stories (1972: 11). These pre-Christian stories survived after the conversion to Christianity, and Beowulf contains allusions to pre-Christian and Christian motifs. Gregory the Great shows himself as working toward a Christian society ruled jointly by kings and bishops on the model described in the Old Testament (Nie 2003: 179). Gregory the Great stated that he intended to substitute stories about divine miracles for those about the actions and metamorphoses of immoral pagan deities; which were still part of the classical education given to young aristocrats. Stories about miracles including dreams, heroic and supernatural elements are delibrately chosen as vehicles to convey the essence of Christian belief (Nie 2003: 180). Gregory the Great also adopted the idea of paganism as a spectrum of beliefs and practices, and he stated that those who were pagans were considered not to have been baptised. As pointed out by Robert Austin, pagans did not know true God, and merely worshiped sticks and stones 
(1997: 82). Although Gregory gives importance to Christianity, he implicitly depicts his ideas in literary works which contain heathen practices. In Beowulf these heathen practices and some events related to The Old Testament support the strategy adopted by Pope Gregory the Great. Similar to the idea of Gregory the Great, Lawrence describes the Christian passages as integrated later into Beowulf:

The religion of the characters seems imposed upon
them rather than natural to them. The poorest and
weakest parts of the poem are to be found among
the definitely Christian passages. The only thing that
is naive about the poem is its theology. Here is
untried material and childlike attitude toward a new
faith. Tradition had not yet taught the poet how to
treat it with technical assurance. But, though ever
present, the Christianity is all on the surface. The real
vitality of the epic lies in its paganism. (1928: 9)

Similar to Lawrence, Whallon believes that the Beowulf poet knows little of Christianity besides two stories from the first nine chapters of Genesis, the story of the Creation and the story of Cain (1965:19). Whallon also asserts that the apparently Christian vocabulary of Beowulf comes, for the most part, from traditional Germanic poetic language. Whallon also emphasizes the fact that the words and phrases for god and the devil probably had originally pagan associations: faeder, alwalda and meotod are as biblical as pater, omnipotens, and fatum, and Beowulf is to this extent neither Christian nor unchristian, but pre-Christian (1965: 20). Stevick offers a theory to explain how an originally pre-Christian heroic poem about Beowulf might have acquired its Christianity. Stevick asserts that:

Beowulf existed for some time as an oral poem before it was copied down. In this pretextual stage, the poem was subject to extensive modification and alteration, and after the conversion of England to Roman Christianity it could have absorbed its Christian elements in the course of being sung by one or more converted oral singers. Christian elements in Beowulf drive first and significantly from 
the normal mutations and accretions in explanation, characterization, and reflective commentary in oral literature of a cultural tradition whose religion had changed more radically than its narative materials and poetic techniques. (1963: 79-89)

The poet of Beowulf has inserted Christian comments and pious exclamations into his poem because he considers them necessary and appropriate. For instance the poet points out the references to God's influence upon the outcome of Beowulf's fight with Grendel's mother when he first narrates the episode:

The hero observed that swamp-thing from hell, The tarn hag in all her terrible strength, Then heaved his war-sword and swung his arm: The decorated blade came down ringing And singing on her head. But he soon found His battle-torch extinguished; the shining blade Refused to bite.

The son of Ecgtheow would have surely perished And the Geats lost their warrior under the white earth Had the strong links and lock of his war-gear Not helped to save him: holy God Decided the victory. It was easy for the Lord, The Ruler of Heaven, to redress the balance Once Beowulf got back up on his feet (1518-56)

In the line 'Holy God decided the victory' the poet refers to pious exclamations about the idea of God as the giver of worldly prosperity, success in battle, and good fortune in general. For instance Beowulf observes that God decides the battle with Grendel:

No weapons, therefore, For either this night: unarmed he shall face me If face me he dares. And may the Divine Lord In His wisdom grant the glory of victory To whichever side He sees fit (685-90)

God saves and helps Beowulf in the fight with Grendel's mother: 
It was hard-fought, a desperate affair

That could have gone badly; if God had not helped me, The outcome would have been quick and fatal.

Although Hrunting is hard-edged, I could never bring it to bear in battle.

But the Lord of Men allowed me to behold-

For He often helps the unbefriended- (1655-62)

Beowulf gives thanks to the king of glory for the treasures he wins from the dragon:

To the everlasting Lord of all,

To the King of Glory, I give thanks

That I behold this treasure here in front of me,

That I have been allowed to leave my people

So well endowed on the day I die (2794-98)

Hrothgar attributes Beowulf's arrival to the favor of God, offers thanks to God for Beowulf's victory over Grendel, and again offers thanks to him for Beowulf's resolution to fight Grendel's mother:

Now holy God

Has, in his goodness, guided him here

To the West-Danes, to defend us from Grendel (381-83)

First and foremost, let the Almighty Father

Be thanked for this sight. I suffered a long

Harrowing by Grendel. But the Heavenly Shepherd

Can work His wonders always and everwhere (928-31)

With that the old lord sprang to his feet

And praised God for Beowulf's pledge (1397-98)

The Geats collectively thank God for their easy voyage to Denmark, and for Beowulf's safe return from the depths of Grendel's pond:

There was a clash of mail and thresh of gear.

They thanked God for that easy crossing on a calm sea (226-27)

His thanes advanced in a troop to meet him, Thanking God and taking great deligh In seeking their prince back safe and sound (1626-28) 
The Danish shore-guard wishes the Geats the favor of God, Wealtheow thanks him for Beowulf's presence in Denmark, and Hygelac thanks God that Beowulf has returned safely home:

May the Almighty Father keep you and in

His kindness watch over your exploit (316-17)

With measured words she welcomed the Geat

And thanked God for granting her wish

That a deliverer she could believe in would arrive

to ease their afflictions (625-28)

So God be thanked

I am granted this sight of you, safe and sound (1997-98)

If the poet of Beowulf is considered to be a Christian, the God to whom he and his characters allude to is the Christian God. When the characters offer thanks, they offer it to the single deity; when the poet attributes the outcome of a battle to a supernatural power, he attributes it to a single deity, and when the poet tells his audince that his characters offer thanks, it is again to a single deity.

The poet's description of a song about the Creation sung by a scop in Heorot is another trace of Christianity that is referred to in the following lines, and Chadwick suggests that two or three Caedmonian poems of the Caedmonian Genesis might have provided all of the Christianity in Beowulf (1912: 394). Although there are some Germanic creation songs such as The Edda and Voluspa, the creation song of Beowulf depicts Christianity sung by a scop:

Every day in the hall, the harp being struck

And the clear song of a skilled poet

Telling the mastery of man's beginnings, How the Almighty had made the earth

A gleaming plain girdled with water; In His splendor He set the sun and the moon To be earth's lamplight, lanterns for men, And filled the broad lap of the world With branches and leaves; and quickened life 
In every other thing that moved (91-96)

Athough there are many implicit pagan gods, there are explicit references to the Old Testament in Beowulf. Blackburn draws attention to these Christian elements containing biblical history or allusions to some scriptural narrative (1897: 205-25). These include references to Cain, Abel, and the Flood. What is clear about the religious colouring of Beowulf is that while it is clearly Christian, there is little Christian doctrine. It seems that Beowulf tells of a period in the midst of religious change being neither entirely pagan, nor fully Christian or was an attempt to integrate Germanic history into the Old Testament time frame (Hamilton 1963: 15). The Christian glossing of the epic can be observed in the way Grendel is described as a descendant of the biblical Cain, the first murderer. Grendel haunts Heorot, the mead-hall of the Danes, and creates chaos. Hrothgar and his society need help and Beowulf leaves Geatland to help the Danes and to defeat Grendel:

\footnotetext{
Grendel's mother, Monstrous hell-bride brooded on her wrongs. She had been forced down into fearful waters, The cold depths, after Cain held killed His father's son, felled his own Brother with a sword. Branded an outlaw, Marked by having murdered, he moved into the wilds, Shunned company and joy. And from Cain there sprang Misbegotten spirits, among them Grendel, The banished and accursed, due to come to grips With that watcher in Heorot waiting to do battle (1258-67)
}

After the death of Grendel, Grendel's mother arrives at Heorot to take revenge. When Grendel's mother appears, she is referred to as the monstrous hell bride, which connotes the concept of hell in Christianity. Although Grendel's mother arrives at Heorot to take revenge, Beowulf kills her. After killing her, he realizes the significance of the sword, which has an allegorical meaning. The hilt's engravings tell the story of "the origin of past strife, when the flood drowned and the pouring 
ocean killed the race of giants" (1689-90). The poet describes the qualities of the sword as follows:

Then the gold hilt was handed over To the old Lord, a relic from long ago For the venerable ruler. That rare smithwork Was passed on to the prince of the Danes When those devils perished; once death removed That murdering, guilt-steeped, God cursed fiend, Eliminating his unholy life

And his mother's as well, it was willed to that king Who of all the lavish gift-lords of the North Was the best regarded between the two seas $(1677-86)$

The hilt is engraved with the story of the Great Flood and the death of the giants from the rising of the sea:

Hrothgar spoke; he examined the hilt, That relic of old times. It was engraved all over And showed how war first came into the world And the flood destroyed the tribe of giants.

They suffered a terrible severance from the Lord;

The Almighty made the waters rise,

Drowned them in the deluge for retribution (1687-94)

These passages illustrate that Beowulf embodies both pagan and Christian elements intermingled with each other.

One of the other important concerns in Beowulf is the presentation of Beowulf as a Christ figure. Bazelmans asserts that there is not such a direct idea about Christ, but the deeds of Beowulf resemble the deeds of Christ (1999: 92). The characters described in Beowulf know the Creator through the creation. Some, like Hrothgar's Danish subjects are true pagans who give themselves over to the worship of idols and who thereby belong to the race of Cain in a spiritual sense (Bazelmans 1999: 93). Others, like Hrothgar and Beowulf, worship and honour God; they are in a spiritual sense neither pagan nor Christian. Beowulf reflects some of Christ's virtues, not in his words but in his deeds. According to Donahue, the development of 
Beowulf is constructed on the basis of the Christian triad: faith, hope and love (1965: 57). In the first part of the poem, Beowulf's non-commital attitude towards God and his excessive trust in his own powers disappear when God gives him solace and support in his battle with Grendel, and in his fight with Grendel's mother he shows him the sword that will bring him victory. With his unselfish conquest and division of the dragon's hoard, Beowulf gives thanks to God like the virtuous and unselfish Christ.

Similar to the influence Christian concept in Beowulf, the polytheism of Germanic and Scandinavian societies influenced Beowulf, and brought forward the idea of paganism and heathenism. In addition to this, polytheism interacts with Christianity especially after conversion to Christianity, and biblical events such as the Flood, the Last Judgement and Cain's slaying of Abel are observed in Beowulf. The implicit figures of the gods before Christianity, and the figura of Christ after conversion to Christianity are also demonstrated in this English epic.

Similar to Beowulf, the traces of polytheism and the concept of monotheism are intervowen in the Turkish epic. The Sky-God belief is considered to be the first belief of the Turks, and it resembles the pagan beliefs reflected in Beowulf. Shamanism is also a religious practice observed in the Sky-God belief. Intrinsic to shamanistic practice is the idea of an interaction with nature spirits in ways which heal, cause other people to become ill or protect the warriors in battle, and practices of shamanism also involve the use of a power animal or a second soul to achieve their ends. The Sky-God belief and shamanism are characterized spiritually, honouring of pre-Islamic deities, personal belief systems, and lack of institutionalization. The traces of the Sky-God belief date back to the Huns and Göktürks, and the Oğuz people were influenced by the Huns and Göktürks. As stated by Güngör and Günay the first traces of the Sky-God belief are observed in 
the sources of the Hun Empire (1998: 34). The gods are grouped in an organized system: the Sky-God is called Ülgen, the god of goodness and the underworld god of the wickedness is called Erlik (Güngör; Günay 1998: 47). Erlik has seven sons; Pay Maattir, Karas, Kerey Kaan, Ucar Kaan, Yabas Kaan, Komur Kaan, Seedey Kaan (İnan 1987: 407). İnan also draws attention to the importance of these sons; although they are not worshipped by the Oğuz society, they have the power that their father has (1987: 408). The sons of Erlik stand for the polytheist belief, but this polytheism does not have the same meaning observed in Beowulf. Hence it can be asserted that polytheism in The Book of Dede Korkut is different from the polytheism in Beowulf, and another term for the polytheism in the Turkish epic should be more appropriate. In this study in order not to confuse the two systems of belief, the term Turkic polytheism will be used when referring to polytheism depicted in The Book of Dede Korkut. In the Sky-God belief, Ülgen is a god and his dwelling place is the mountaintops, tops of the trees or the sky. In The Book of Dede Korkut the black mountain is considered to be the house of Ülgen and it is one of the major cults among the Oğuz tribes, but after the influence of Islam the poet of The Book of Dede Korkut does not give any information about the Sky-God, but he praises the sublimity of Allah:

Hear my words and listen to me, Bay Püre Bey, Almighty Allah gave you a son, and may He preserve him. May he ever be followed by Moslems as he bears his white banner. When he has to cross those snow-covered black mountains, Lying yonder, may Allah help him to cross them When he has to ride through bloody rivers, May Allah grant him safe passage. When he has fallen among the crowds of infidels, May Allah give him yet a chance. (44)

Although the influence of Islam is observed in these lines, "snow-covered black mountains" stand for the dwelling place of Ülgen. 
In shamanism, the will of the ancestral spirits, ecstatic seizures and flying mounts are important concepts. Ripinsky points out the fact that such sacred places are the dwelling places of the supernatural beings and the names of these places are not explicitly given (1993: 59). Shamans are considered to be godlike creatures and they have supernatural powers to set the world in order. As mentioned by Baldick, the usual Turkic word for shaman or "qam" means diviner and Baldick also asserts that the shamans murmur magical phrases, prepare a spell, and draw an omen. The concept of Turkic shamanism can be observed in the figure of Dede Korkut. Korkut Ata was an adviser of the Oghuz people in all-vital matters, and nothing was done before he was consulted. Whatever advice he gave was accepted and acted upon. Among his wise sayings were those, which follow:

Nothing goes well without mentioning the name of Allah. No one can prosper without the will of Almighty Allah. Nothing happens if it was not already written down in the beginning No one dies before his appointed hour. (3-4)

In these lines Korkut Ata is presented as a bard, an epic singer-teller or shaman, who composes the epic and sings and narrates it to the accompaniment of his lavta ${ }^{3}$; he is also the wise man and the sorcerer-magician of the Oğuz people. Başgöz points out that Korkut Ata combines in his personality the characteristics of a mythical ancestor, a shaman-sorcerer of the pre-Islamic era, a political counselor of the rulers, and a Muslim Saint (1978: 313$)$.

Similar to the concept of the Sky-God belief and shamanism in The Book of Dede Korkut, the concept of the bridge is of significance. The shamans have to cross over a bridge in order to reach the Underworld. The Underworld signifies hell in shamanism. Eliade points out that the bridge forms a tie between the Sky and the

\footnotetext{
${ }^{3}$ It is an ancient fretless string instrument and it is generally made from a single piece of wood and has three strings traditionally made out of gut, modernly made from fishing line.
} 
Underworld, and it helps people and gods to communicate (1999: 525). In the story of Deli Dumrul a bridge is described at the very beginning of the story. Deli Dumrul is portrayed as a nonMuslim and the shaman motifs with Turkic polytheism are indirectly stated as follows:

My khan, among the Oghuz people there was a man by the name of Deli Dumrul, the son of Duha Koja. He had a bridge built accross a dry riverbed. He collected thirty-three akchas from anyone who passed over it, and those who refused to pass over he beat and charged forty akchas anyway (89).

An interesting point is that Deli Dumrul builds his bridge across a dry riverbed. In this respect it may be argued that the bridge is not to pass over, but to signify the interaction between hell and heaven. In shamanism the sky refers to heaven, the underworld refers to hell (Balzer 1990: 35). Deli Dumrul believes in this spiritual practice and ignores Islam at the very beginning, so he may stand for a shaman and ask people to pass over his bridge because he wants these people to be aware of shamanism. In the end of the story, Deli Dumrul converts to Islam. Although it is not written in Quran, after the interaction of Turk Muslims and Zoroastrian Muslims, the concept of "Chinvat Bridge" or "Sırat" is introduced. According to this so-called belief when all the Muslims die, they will pass over this bridge: those, who pass over the bridge, will have the chance to reach heaven; those, who fall down while passing over the bridge, will be punished and go to hell (Boyce 1979: 13). Deli Dumrul always stands over his bridge, and it may be an implicit sign that he will be rewarded by God by reaching heaven after one hudred and forty years:

Almighty Allah was pleased with Deli Dumrul's words. He gave his orders to Azrail: "Take the lives of Deli Dumrul's father and mother. I have granted a life of 140 years to this lawfully married couple." Azrail 
proceeded to take the lives of the father and mother right away, but Deli Dumrul lived with his wife for 140 years more. (97)

Within the Sky-God belief and shamanism there are various other cults, which the Oğuz Turks believed in. First of all the tree cult was of great importance: the first person was created under a tree, and the tree was the first place where Ülgen and man encountered (Ögel 1971: 419, Çoruhlu 2002: 111). For this reason the image of the tree is considered to be the symbol of Ülgen in The Book of Dede Korkut (Sakaoğlu 2003: 140).

In a tree cult, God is symbolized as a tree (Ögel 1971: 166). An interesting point is that the tree cult is observed before Islam, and it refers to one god, but each cult has its own god befitting the Turkic polytheism and shamanism. For instance the tree, which stands for god, has to be a single one, because God is the only one and does not resemble anything or anyone. Secondly, the tree never sheds its leaves, implying its immortality, and this aspect sybolizes the immortality of God and the universe as well. Thirdly, the holy tree has to be the tallest or the biggest among the other trees, if the tree is the biggest and the tallest, it sees everywhere; similar to God who is the owner of the world and can see, hear, and know everthing. Futhermore the holy tree does not have any fruit, which means the tree does not give birth, and also implies that God never gives birth. The tree has to be the oldest among the other trees; it stands for the infinity of a tree. In addition to this, the holy tree has to be large, if this holy tree is large enough, it may save all the things, similarly God saves all the living and non-living things. As stated by Ülkütaşır, in the pre-Islamic period the ancient Turks considered trees sacred, and some tribes such as the Oğuz people believed that their ancestors were trees (1938: 30-37). One of the Turkish creation myths pictures the parents of mankind as a beech tree (the father) and a hazelnut tree (the mother). After a column of sacred life descended 
upon these trees one night, the hazelnut tree became pregnant. Nine months later a door opened in the trunk of this tree and out of it jumped five babies. When these babies grew to be fifteen years old they asked who their parents were. When they were told that their parents were the beech and the hazelnut trees, they went to these trees to pay their respect. The trees talked to them and before they left blessed them (Sümer, Uysal, Walker 1972: 187). The tree cult is considered to be one of the beliefs before Islam, and when The Book of Dede Korkut was put down into writing, the uncertainty of the tree God and Islamic God is asserted. For example, in The Book of Dede Korkut, the tree is considered to be God in the story of "The Sack of the House of Salur Kazan". Salur Kazan addresses a tree and says:

Be not offended $\mathrm{O}$ tree, by my calling you tree The Gates of Medina and Mecca were made of you.

The staff of Moses, to whom Allah spoke, was of you, too.

The bridges that cross great rivers are made of you

The ships in the dark, dark seas are made of you.

The saddle of Ali, leader of gallant men, was made of your wood.

The handle and sheath of Zulfikar, his sword, were made of you

The cradle of Hasan and Huseyin was of your wood.

Women and men are equally frightened by you.

When I look upward, I see not your head;

When I look downward, I see not your roots.

If they hang me from you, support me not.

If you do, then would that my youthful vigor could stop you, oh, tree.

If then you should stand in my land, oh, tree

I should order my slaves, black Indian slaves,

To tear you apart in a thousand pieces, oh tree. (33-34)

Although the tree is a symbol of God, the name Allah, is also used in these lines. After the conversion to Islam, the poet cannot ommit the pre-Islamic elements. The leaves and the roots of this holy tree cannot be seen, the top leaves reach heaven and this is the dwelling place of the Sky-God; the roots of the tree reach hell, which is the dwelling place of Erlik or Satan. İnan also draws attention to the fact that the ancestors of Uruz hang the corpse of the dead up the tree to help his soul reach the Sky-God (1987: 187). In this respect it may be argued that the ancestors of 
the Oğuz people also believed to reach the Sky-God, and implicitly heaven. The tree cult in The Book of Dede Korkut is reminiscent of the concept of the holy tree, which is called Yygdrasil in Scandinavian and Germanic cultures (Kendrick 1994: 124). Yygdrasil is a huge tree whose roots and branches hold the earth, heaven and hell and underworld together in Scandinavian mythology. Havamal is one the well-known Scandinavian poems, and in this poem it is implicitly referred to Yygdrasil (Clarke 1923: 79).

In the tree cult of Scandinavian and Germanic mythologies, Yygdrasil may stand for god. Yygdrasil's roots symbolize hell, the god of evil, and its upper branches stand for god of heaven and heaven itself. This world of tree is god and the three roots of Yygdrasil stand for the god of evil. These three roots are respectively Asgard, Midgard and Niflheim. Asgard is the abode of gods, Midgard is the abode of mankind and the earth, and Niflheim stands for the outer region of cold and darkness, abode of hell. Niflheim is also a serpent that gnaws upon the lowermost root of Igdrasil. The trunk of this Scandinavian tree refers to the world where all the non-living things and living things exist, and the upper branches of this holy tree symbolize heaven (Bosworht 1836: 16). Kendrick also mentions that the oak tree is of significance in Scandinavian mythology, and the branches of the sacred tree symbolize God or the King of Trees (1994: 125). The Yygdrasil image also depicts the tribes of the societies. Each tribe of the society has a leader, and this leader has his tree. In this respect this tree has literal and metaphorical meanings. First of all, the leader has his tree, and the leaves of this tree are always evergreen, it never sheds its leaves till the leader dies. When he dies, his tree dries also. Secondly, the tree stands for the generation of the society that the leader belongs to. The leader is the representative of his society, and his retainers follow him. If the leader dies, his dynasty also collapses. Similar to this idea, in the story of 
the capture of Uruz Bey, the line "You should stand in my land" supports the idea of the Oğuz people's identity. In this line land refers to the dynasty of the Han. In The Book of Dede Korkut each tribe has its own roots and family tree, which symbolize both the Han and God. This is also a sign of the rule of the Sky-God and the continuation of the race. If one dies or is killed, his tree is cut, so this means the race of the Oğuz people will not continue and the Oğuz society will not feel the power of God (Ögel 1995: 468). Another example of the application of the holy tree cult is in the story of Basat, killer of the one-eyed giant. When Basat is boasting and making his lineage known, he says:

In confusion of battle I stand in broad daylight;

If I pass into darkness, the source of my hope lies in Allah.

Our standart is now held by Bayindir Khan

Our leader who rides at front on the day of battle

Is Salur Khan, the son of Ulash.

If you wonder about the name of my father,

Then know it is Big Tree

If you wonder about the name of my mother

Then know it is Royal Line,

If you ask me my name, it is Basat, the son of Uruz. (131)

The holy tree is the symbol of God, and the Khan is the representative of God. Basat, the son of Uruz, is the leader of his dynasty and protects his society from disasters. Tepegöz is considered to be a supernatural creature and it disturbs the dynasty of Basat. Being the leader, it is his responsibility to protect his society from Tepegöz. In his words, Basat tries to state that in contrast to his status, Tepegöz comes from hell and he is the representative of Satan or hell (Sakaoğlu 2003: 145). Basat refers to the Big Tree by means of his ancestors. As stated above, in Turkish mythology the Han or kağan is sent to the world by the help of the tree, or a mother gives birth inside a tree, hence it may be asserted that the tree is God, and all the heroes come from heaven to the world by means of the holy tree (Ögel 1971: 101). When the characters in The Book of Dede Korkut need to pray, they 
address the holy tree or God himself: "May your snow-covered mountains remain standing and your strong shade trees be not cut down, and may Almighty Allah never allow you to lie at the mercy of the wicked" (39).

Hence it may be asserted that all these instances support the coexisting traces of polytheism and monotheism in The Book of Dede Korkut. Similarly in the story of Bamsı Beyrek, the trace of the tree cult is also observed: the sister of Bamsı Beyrek is very sad and cries all the time for his lost brother by implying the tree:

The black mountain over there is falling down, But, minstrel you are not aware. My great shade tree is being felled But minstrel you are not aware A brother has been taken from me But minstrel you are not aware Do not play or sing now, minstrel; What comfort can it bring a grieving girl?

There is a wedding farther on. Go play your lavta there. (60)

The tree image is referred to with the words "my great shade tree" to mean "Kaba Ağaç" in Turkish. The big tree metaphorically stands for the dynasty of Bamsı Beyrek. In the story, this big tree is going to be cut, which means Bamsı Beyrek's dynasty will collapse. Bamsı Beyrek, the brother of the girl is lost and his dynasty is in danger, for this reason the sister weeps and refers to this big, dry tree, which is on the verge of being cut. When the sister realizes that her brother is alive, she expresses her feelings of joy by referring to the holy tree again:

Your black mountains had fallen, but now they are rising again. Your stream stained with blood had dried up, but now they are flowing again.

Your tall tree had withered, but now it is green once again. Your fine horse had grown old, but once more bears a colt. Your red camels had aged, but now they have young ones again. Your white sheep had aged, but now they have lambs in the fold, And Beyrek your son, who was gone sixteen years, has returned. My father and mother, what gift will you give for good news? (67) 
The regeneration of the dry tree refers to Bamsı Beyrek's dynasty and his sublimity. His tree would have been cut, but when he comes back, his tree does not wither, but its leaves turn green again. In addition to this when the tree has its green leaves, his sublimity is observed: the holy tree is a metaphor for Ülgen, and Bamsı Beyrek attains him. Hence this line implicitly refers to the happiness of the sister because she is also aware of this fact.

The tree image is also stated in the story of Seğrek. When the infidels capture Seğrek, his mother mourns all the time, and when the brother of Segrrek comes and asks her mother for permission to save Seğrek, the mother burst into tears:

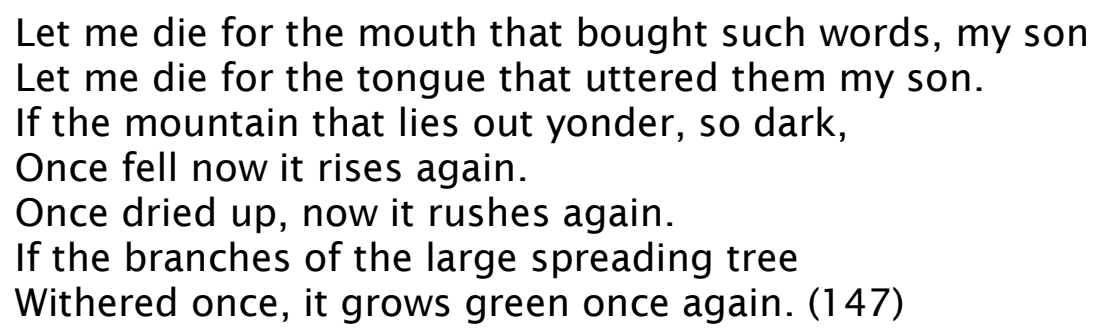

The reason for her weeping is that she is not sure whether he is alive or not. She is also aware of the fact that if Seğrek is alive, his dynasty will continue. The branches growing green once again refer to his dynasty, and the mother hopefully waits for her son and for the continuation of his line. When the branches of the tree get green again, Seğrek's mother expresses her joy.

Cults observed in The Book of Dede Korkut are the water and mountain (Eliade 1999: 298). The Oğuz society believed that water and the cosmic mountain connected the sky and the earth like God. In the story of the Sack of The House of Salur Kazan, Salur Kazan addresses nature:

Oh, water that gushes from under the rocks!

Oh, water that tosses the ships made of wood!

Oh, water once sought by Hasan and Huseyin!

Oh, water, a treasure for gardens and vineyards!

Oh, water, so cherished by Ayse and Fatma; 
Oh, water, the drink of all beautiful horses;

Oh, water drunk deeply by thirsty red camels;

Oh, water near which lie the flocks of white sheep.

Do you know what disaster has come to my camp?

Oh, speak!

May my luckless head be a sacrifice to you. (28)

The word 'water' refers to the polytheistic Turkic god and Salur Kazan tries to solve his problem by asking questions to god. He is in a desperate condition: when he reaches home after a long journey, he finds nothing left of his dynasty. In this respect he prays to water because water stands for the Turkic god in the Sky-God belief and shamanism.

It is debated whether The Book of Dede Korkut was composed and put down into writing by a single poet or multiple poets. If it is considered to be a single poet, the poet of the Turkish epic may be said to be a Muslim. As Türkdoğan states, he celebrates the nobility of the Oğuz tribes, which once knew the Sky-God belief and its cults and shamanism (1987: 780). If the composer and the writer of the Turkish epic is a single poet, he speaks of Allah and of the devil, and he alludes specifically to Islamic events such as the deeds of Azrail, the sins of the worldly affairs, the importance of family, hospitality and the holiness of virtues, but it is implied that the Turkish epic does not aim to depict only the religious perspective (Ergin 1989: 27). In the poem, the thoughts of the characters and their language are circumscribed by the pre-Islamic world in which they live, and when their speeches seem to have an Islamic resonance, the audience is expected to recognize that these are but coincidences of similar elements in two different cultures, coincidences which inevitably give dignity to the old heroes as viewed by pre-Islamic and Islamic eyes. In this respect it may be asserted that the poet and/or the poets who composed or put it down into writing are anonymuous. It may also be argued that the composer/s or the poet/s of this(these) epic(s) is/are (a) shaman in the Sky-God 
belief and shamanism. As Binyazar states although there is no reliable information about the identity of the poet of The Book of Dede Korkut, there are some clues and historical documents about his identity (1996: 9). Dede Korkut is called Korkut Ata and he is considered to be a shaman, but it is not clear whether he is the composer, the poet or the person of authority in the epic. The Book of Dede Korkut is a product of the Oğuz society, and in the epic as a shaman Korkut Ata is depicted as a leading figure who heals the wounds of the Oğuz society, helps them whenever they need him; he sometimes goes to the top of the mountain to meet Ülgen, he sometimes goes to the Underworld to meet Erlik. Thus, the Sky-God belief and shamanism have been mingled in the epic before conversion to Islam.

As the Oğuz society converted to Islam in the eleventh century, the traces of Islam were incorporated into the Turkish epic, and the polytheistic and monoteistic elements coexist in the epic. Another example for this is the figure of Azrail. In Islam Azrail is one of the angels, who seperates the soul from the body. Azrail and his deeds are narrated in the story of Deli Dumrul, the son of Duha Koca. Deli Dumrul, who is a valiant hero, does not believe in the holiness of Azrail and the dignity of Allah. He wants to fight with Azrail to save the lives of people, but Almighty Allah is not pleased with Dumrul's attitude, and wants to punish him, and orders Azrail to go and see the hero:

While Deli Dumrul was sitting and drinking with his forty companions, Ezekiel suddenly arrived. Neither the chamberlains nor the wardens had seen Ezekiel pass. Deli Dumrul's eyes were blindened, his hands paralyzed. The entire world was darkened to his eyes. (90)

Deli Dumrul realizes that the red-winged Azrail wants to take his life and prays:

Oh Ezekiel, have mercy!

There is no doubt about the unity of Allah. 
I was uninformed about you

I did not know you secretly took lives.

We have mountains with large peaks;

We have vineyards on those mountains;

In those vineyards there are vines with bunches of black grapes;

And when pressed those grapes make wine, red wine.

A man who drinks that wine grows drunk.

Thus I was drunk, and so I did not hear.

I did not know what I had said.

I have not tired of the role of bey.

I wish to live out more years of my youth,

Oh Ezekiel please spare this life of mine. (92)

Deli Dumrul does not believe in Islam at first and he feels valiant enough to fight

with Azrail. When he realizes Azrail's eternal power, he stops being arrogant, understands the dignity of Allah, and converts to Islam:

Thou art higher than the highest;

No one knows how high you are,

Allah the Magnificent!

Fools search for you in the sky on earth

But you live in the heart of the faithful

Eternal and merciful Allah,

Let me build needed homes for the poor

Along the main roads of the land

Let me feed hungry men for your sake when I see them

If you take any life, take the lives of us both.

If you spare any life, spare the lives of us both,

Merciful Almighty Allah. (96-97)

Azrail is one of the angels of Allah in Islam and Deli Dumrul prays to be forgiven by Allah. In The Book of Dede Korkut not only Allah and Azrail, but also the prophets are of significance. Islam accepts all the prophets, but underlines that Mohammed is the last prophet. Mohammed is directly referred to in this Turkish epic: "Shortly before the time of the Prophet, there appeared in the Bayat tribe a man by the name of Korkut Ata" (3).

After the conversion to Islam, the Oğuz society follows the doctrines of Islam. In Islam Allah is the only one, and the Holy Koran is the last Holy Book. Dede Korkut comes and plays the lavta and tells heroic tales about Muslim heroes: 
Those who once claimed the world Taken by death and concealed by earth. To whom has the world been left at last The world with its coming and going The world that is rounded off by death?

Death is the end of long life; seperation is the ultimate fate of all. Let me pray, my Khan. May you not deviate from your clean faith at the time of death. May your white bearded father's place in the next world be paradise. May your white haired mother's place be in paradise, too. May Almighty Allah never leave you at the mercy of the cruel and mean. We have offered a prayer of five words in your presence. May it be accepted. May those saying 'Amen Amen' come to see the face of Allah. May He save you from your sins and forgive them for the sake of Mohammed Mustafa, O my khan. (175)

In this prayer the Islamic concepts of death and fate are referred to. Death is an inevitable concept and fate is shaped by Allah's orders. These lines refer to the sublimity of Allah, and his prophet Mohammed. Allah forgives all the mortals, and although Mohammed is the prophet, he is a mortal as well. Similar to the significance of Allah, Mohammed and Azrail, The Holy Book Koran is mentioned in The Book of Dede Korkut that refers to Islam: "Uruz brought the Koran on which they all pressed their hands and took an oath saying, "We are friends with your friend and foes to your foe" (170).

Dede Korkut was a shaman before conversion to Islam, and he had some supernatural powers to heal the Oğuz society. After the conversion to Islam Dede Korkut appears to be the "Derviş" instead of a shaman, and he represents the values of Islam:

Dede Korkut was at a loss what to do. He asked for the protection of Allah, reciting the İsmi Azam prayer. Delü Karchar drew his sword and aimed a terrible blow intended to knock Dede Korkut down. Dede Korkut said," If you strike me may your hand dry up." At the command of Almighty Allah Delü Karchar's remained in the air, for Dede Korkut was 
endowed with power like that of a Saint, and his wish granted. (48)

These lines refer to the importance of Korkut Ata, and that he stands for a pious person after conversion to Islam.

In both of the epics the concept of god changes and varies. It may be asserted that polytheistic and monotheistic beliefs establish the essence of Beowulf, because Beowulf depicts a period of transition from polytheism to monotheism, that is, from Nordic pagan beliefs to Christianity. Similar to Beowulf, The Book of Dede Korkut also reflects a period where polytheistic and Islamic elements and ideas coexist. Before the monotheistic beliefs such as Christianity and Islam, paganism and Druidic shamanism in Beowulf and the Sky-God belief and cults and Altay shamanism are observed in The Book of Dede Korkut. In this respect although these epics display similarities in reflecting polytheism, they differ from each another to some extent: in Beowulf pagan gods are worshipped, but in The Book of Dede Korkut gods are not worshipped; only the son and daughter names of Ülgen and Erlik are given, but there is no implication that they were worshipped. Furthermore the monotheistic God as described in Beowulf and The Book of Dede Korkut is similar, but the religions are different: they are respectively Christianity and Islam. Beckett asserts that it is tempting to assume that after conversion to monotheistic beliefs, both believers of these religions encountered on the way to their pilgrimages in 884 $A D$, and Christians carried goods and ideas from Islamic territories (2003: 53). In this respect it may be argued that if there was such a contact, the religious ideas of these monotheistic beliefs (and also the polytheistic beliefs) would presumably influence each other. When the epics were put down into writing, they would probably carry the hints of this interaction. 


\section{Works Cited}

Austin, Robert. Gregory the Great and His World. Cambridge: Cambridge University Press, 1997.

Baldick, Julian. Animal and Shaman. New York: New York University Press, 2000.

Balzer, Marjorie. Shamanism. New York: M.E Sharp, 1990.

Barrett J.C. ; " The Monumentality of Death: The Character of Early Bronze Age Mortuary Mounds in Southern Britain”. World Archeology, 22(1990), 179-83.

Başgöz, İlhan. Heroic Epic and Saga. London: Indiana Uni. Press, 1978.

Bazelmans, Jos. By Weapons Made Worthy. Amsterdam: Amsterdam University Press, 1999.

Beckett, Katharine Scarfe. Anglo-Saxon Perceptions of the Islamic World. Cambridge: Cambridge University Press, 2003.

Binyazar, Adnan. Dede Korkut. İstanbul: YKY, 1996.

Bjork, Robert E, John D. Niles. A Beowulf Handbook. Lincoln: University of Nebraska Press, 1997.

Blackburn F.A. ; "The Christian Colouring in the Beowulf in an Anthology of Beowulf Criticism", PMLA 12(1897), 205-25.

Bosworth, J. Scandinavian Literature with short Chronological Specimens of the Old Danish, Iceland, Norwegian, Swedish. London: Longman, 1836.

Boyce, Mary. Zoroastrians. London: Routledge\&Kegan Paul, 1979.

Bruce- Mitford, R.L.S.1968; "SuttonHoo Excavations" 1965-7 Antiquity 42, 36-9.

Chadwick, Munro. The Heroic Age. Cambridge: Cambridge University Press, 1912.

Cherniss, Michael. Ingeld and Christ. Paris: Mouton, 1972.

Clark, George. Beowulf. Boston: Twayne Publishers, 1990.

Clarke, Martin. The Havamal. Cambridge: Cambridge University Press, 1923.

Crossley-Holland, Kevin. Beowulf. New York: Farrar, Straus, and Giroux, 1970.

Çobanoğlu, Özkul. Türk Dünyasında Epik Destan Geleneği. Ankara: Akçağ, 2003.

Donahue, Charles.;" Beowulf and Christian Tradition: A Reconsideration from a Celtic Stance", Traditio 21(1965), 55-116.

Donoghue, Daniel. Ed. Beowulf. Trans. Seamus Heaney. London: Norton\&Company, 
2002.

Eliade M. Dinler Tarihine Giriş, (Çev.: Lale Arslan) İstanbul: Kabalcı, 1999.

Elibeyzade, Elmeddin. Kitab-ı Dede Korkut. Bakı: Yazıcı, 1988.

Ergin, Muharrem. Dede Korkut Kitabı I: Giriş- Metin-Faksimile. Ankara: TTK Basımevi, 1989.

Godden, Malcolm. Biblical Literature: The Old Testament. np: Godden and Lapidge Edition, nd.

Hamilton, Marie Padgett. The Religious Principle in An Anthology of Beowulf Criticism. np: University of Notre Dame Press, 1963.

Hill, Thomas D. The Christian Language and Theme of Beowulf. London: Norton Company, 2003.

İnan, Abdülkadir. Makaleler ve Incelemeler. Ankara: TTK Yayınları, 1987.

Kendrick, T.D. The Druids. Middlesex: Tiger Books, 1994.

Klaeber, F.R. Beowulf and the Fight at Finnsburg. Boston: Heath and Company, 1950.

Legouis, Emile. A History of English Literature. London: J.M Dent and Sons LTD, 1943.

Nebiyev, Bekir.; “Kitab-ı Dede Korkut Ansiklopedisi”, Bilge Dergisi 25(2000), 66-69.

Nie Giselle de. World Image And Experience. Ashgate: Ashgate Publishing, 2003.

North, Richard. Heathen Gods in Old English Literature. Cambridge: Cambridge University Press, 1997.

Orchard, Andy. A Critical Companion to Beowulf. Cambridge: Brewer, 2003.

Ögel Bahaeddin. Türk Mitoloji. İstanbul: MEB Yayınları, 1971.

Ögel, Bahaeddin. Türk Mitolojisi, II. Cilt. Ankara: TTK Yayınları, 1995.

Ripinsky, Micheal. The Nature Of Shamanism. New York: State University of New York Press, 1993.

Sakaoğlu, Salim, Ali Duymaz. İslamiyet Öncesi Türk Destanları. İstanbul: Ötüken, 2003.

Sümer, Faruk, Ahmet Uysal and Warren Walker. The Book of Dede Korkut. Austin: University of Texas Press, 1991.

Türkdoğan, Orhan. ; “Dede Korkut Kitabında Milli Kültür Tipleștirmeleri”, Türk 
kültürü 204 (1987).

Ülkütaşır, M.Ş. Türk Halk Bilgisine Ait Araştırmalar. İstanbul: Eminönü Halkevi Yayınları, 1938.

Whallon, William.; "The Idea of God in Beowulf”, Pmla Lxxx (1965), 19-23.

www.nationmaster.com/encyclopedia/Thorkelin 